\title{
ANP model for evaluating the performance of adaptive façade systems in complex commercial buildings
}

\author{
Ibrahim Yitmen and Amjad Al-Musaed \\ Construction Engineering and Lighting Science, Jönköping University, \\ Jonköping, Sweden, and \\ Fikri Yücelgazi \\ Civil Engineering, Bahçeşehir Cyprus University, Nicosia, Northern Cyprus
}

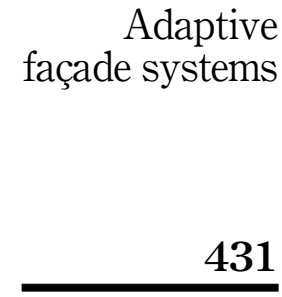

Received 23 July 2020 Revised 20 October 2020

17 December 2020

30 January 2021

Accepted 8 February 2021

\begin{abstract}
Purpose - Decisions taken during the early design of adaptive façades involving kinetic, active and responsive envelope for complex commercial buildings have a substantial effect on inclusive building functioning and the comfort level of inhabitants. This study aims to present the application of an analytic network process (ANP) model indicating the order of priority for high performance criteria that must be taken into account in the assessment of the performance of adaptive façade systems for complex commercial buildings.

Design/methodology/approach - The nominal group technique (NGT) stimulating and refining group judgments are used to find and categorize relevant high performance attributes of the adaptive façade systems and their relative pair-wise significance scores. An ANP model is applied to prioritize these high performance objectives and criteria for the adaptive façade systems.

Findings - Embodied energy and $\mathrm{CO}_{2}$ emission, sustainability, energy saving, daylight and operation maintenance were as the most likely and crucial high performance criteria. The criteria and the weights presented in this study could be used as guidelines for evaluating the performance of adaptive façade systems for commercial buildings in planning and design phases.

Practical implications - This research primarily provides the required actions and evaluations for design managers in accomplishing a high performance adaptive façade system, with the support of an ANP method. Before beginning the adaptive façade system of a building design process, the design manager must determine the significance of each of these attributes as high performance primacies will affect the results all through the entire design process.

Originality/value - In this research, a relatively innovative, systematic and practical approach is proposed to sustain the decision-making procedure for evaluation of the high performance criteria of adaptive façade systems in complex commercial buildings.
\end{abstract}

Keywords Adaptive façade systems, Complex commercial buildings, Multi-criteria decision making, ANP Paper type Research paper

\section{Introduction}

Façade as a building component represents the main constituent of the building climatic skin, and it provides physical comfort for building users (Sadineni et al., 2011). In buildings, it is crucial to ensure controllable isolation, daylighting, change of lucent heat, solar shading, control of humidity, ventilation and energy collecting in adaptable façade systems (Loonen et al., 2015; Sandak et al., 2019). The diversity of technical solutions applied to create

(C) Ibrahim Yitmen, Amjad Al-Musaed and Fikri Yücelgazi. Published by Emerald Publishing Limited. This article is published under the Creative Commons Attribution (CC BY 4.0) licence. Anyone may reproduce, distribute, translate and create derivative works of this article (for both commercial and noncommercial purposes), subject to full attribution to the original publication and authors. The full terms of this licence may be seen at http://creativecommons.org/licences/by/4.0/legalcode

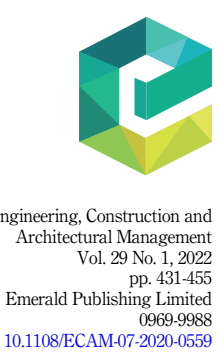


ECAM

29,1 "high performance" commercial building façades are built on basic building physics conceptions for daylighting, control of solar heat collecting, ventilation and inner space acclimatizing (Lee et al., 2002). Façade adaptivity (a self-setting of specific façade's features) can be illustrated in different ways: by the physical modification of the façade configuration, dynamic regulation of the energy flow or activating the concept of clean and renewable energy (Perino and Serra 2015; Sandak et al., 2019). Adaptive façades, especially, comprise of multi-purpose, extremely adaptive systems, wherein the physical partition between the indoor and outdoor area can modify its tasks, characteristics or behavior over time in reaction to temporary functioning requirements and boundary settings in order to boost the complete building performances (Loonen et al., 2015; Romano et al., 2018). The concept of adaptive façade is properly incorporated with European Union (EU) future view of nearly zero energy building (nZEB), considering that adaptive façades have a confident influence on the indoor environment condition caused by considerable decreases in usage of building energy and $\mathrm{CO}_{2}$ emissions (Loonen et al., 2015; Sandak et al., 2019). Adaptive façades are able to increase the efficacy of building's energy and economics, by means of the potential to modify the behavior in real time in line with interior-exterior environment factors, utilizing materials modules, and procedures. Consequently, adaptive façades are able to achieve a major and sustainable influence to accomplishing the targets of EU's 2020 (European Commission, 2012). A number of various forms of adaptive façade models were previously created, and a rise in promising, novel products is anticipated in the coming years (Romano et al., 2018).

There is a challenge to find the gaps associated to adaptive façade systems' assessment necessities and procedures and to deliver perceptions of recent developments and potential challenges in this field. Attia et al. (2018) present an evaluation structure with key performance indicators (KPIs), proposed to construct the evaluation of necessities, performance criteria and technical qualitative features of adaptive façade systems. Romano et al. (2018) built a narrative, behavioral and procedural approach in exploring the topic of high performance façades that encompass substantially novel and response-based systems. Boeke et al. (2019) compiled the exterior limit settings and interior well-being conditions of adaptive façades. A superposition matrix was developed for the evaluation of performance-fit adaptive façade tasks. Hosseini et al. (2019) developed a theoretical framework for creating a morphological method for designing kinetic façade throughout interdisciplinary exploration.

The use of multi-criteria decision-making (MCDM) approaches in the construction industry is gaining growing attention with technological developments and rising functioning demands of building systems and components (Hopfe et al., 2012, 2013; Balcomb and Curtner, 2000). Currently in order to achieve maximum efficiency in their designs, engineers move from conventional design approaches focused primarily on practice to implementation of systematic decision-making processes (Wong and Li, 2008; Brauers et al., 2008; Zavadskas et al., 2008; Si et al., 2016). The design of building façade is one of the fields that is required to formulate and increase the building performance, particularly in respect to the energy efficiency and system influence on the ecosystem that are currently primary problems. The use of MCDM approaches for façade design procedure is exceptionally new and limited (Šaparauskas et al., 2011; Raphael, 2014). The current literature has been primarily concerned with accounting for the ecological, financial and social impact of façade systems, while concentrating on the development of sustainable façade systems. Zavadskas et al. (2008, 2013) and Nadoushani et al. (2017) examined multiplecriteria based techniques for the selection of façade systems employing sustainability measures. Moghtadernejad et al. (2018) classified the prospects from an appropriate MCDM technique for the design of façade systems and compared numerous generally applied MCDM practices. Mirza et al. (2019) presented a Choquet-based design approach to obtain the fuzzy rations for design of building façades. 
Analytic hierarchy process (AHP) and analytic network process (ANP), as mathematically based MCDM tools, are used to measure especially intangible factors by using pairwise comparisons with judgments that represent the dominance of one element over another with respect to a property that they share (Chung et al., 2005). The ANP is a generalization of the AHP. Many decision problems cannot be structured hierarchically because they involve the interaction and dependence of higher-level elements in a hierarchy on lower-level elements (Saaty and Ozdemir, 2005). While the AHP represents a framework with a unidirectional hierarchical AHP relationship, the ANP allows for complex interrelationships among decision levels and attributes (Yüksel and Dağdeviren, 2007). Sasirekha et al. (2015) signified that uncertainty and vagueness during the pairwise comparison process is eliminated through fuzzy data in fuzz AHP (FAHP). However, Bostancioglu (2020) pointed out that the FAHP and AHP method proposed the same alternative as the best choice. Both methods have generated the same ranking in a calculation made with priority weights based on the results presented at the end of the case study involving double skin façade assessment. On the other side, technique for order preference by similarity to ideal solution (TOPSIS) is a method of compensatory aggregation that compares a set of alternatives by identifying weights for each criterion, normalizing their scores and calculating the geometric distance between each alternative and the ideal alternative (Penades-Pla et al., 2016). Consequently, the TOPSIS works one-way and is a method that is mostly used in a single alternative selection and results in almost the same as AHP (Widianta et al., 2018). In recent years, the ANP is one of the most widely practiced methods for MCDM in the sustainable building design process. The most significant feature that characterizes the ANP method from the other MCDM methods, such as TOPSIS, FAHP, elimination and choice translating reality (ELECTRE) and preference ranking organization method for enrichment evaluation (PROMETHEE), is the feedback between the criteria and inner and outer dependencies. In fact, the ANP model provides good traceability of the decision made and a quality assurance given by consistency indexes (CIs) and facilitates more efficient and realistic decisions (Yücelgazi and Yitmen, 2020). The ANP has the ability to handle multiple, correlated and conflicting criteria (Sayyadi and Awasthi, 2018). The ANP as a network structure can accommodate complex relationships to provide more accurate results (Atmaca and Basar, 2012). The ANP is a versatile comparison method that uses internal and external dependencies and gives importance to all factors by ranking according to the priority values of the factors under more than one category, not choosing an alternative (Kadoić, 2018). Since this study did not concentrate on selecting a single factor and did not contain uncertain human preferences as input information in the decision-making process, the ANP model was preferred to obtain a comprehensive result.

Decisions taken during the early design of adaptive façades involving kinetic, active and responsive envelope for complex commercial buildings hold a considerable influence on total building performance and the degree of comfort of inhabitants. Therefore, design of adaptive façade for complex commercial buildings requires an evaluation of multifunctional attributes like energy efficiency and environment, indoor comfort conditions, performance related functions and adaptivity. Design managers are encouraged to implement improved optimization techniques for achieving a balance between the essential performance qualities. This study aims to present the application of an ANP model indicating the order of priority for high performance criteria that must be taken into account in the assessment of the performance of adaptative façade systems for complex commercial buildings.

In section two, the applicable high performance attributes for the selection of adaptive façade system are identified and categorized. Section three includes an ANP developed to prioritize these high performance objectives and criteria for alternative adaptive façade systems. In section four, multifunctional attributes for adaptive façade system are prioritized by using Super Decisions software. Section five discusses the results. In section six, 
ECAM

29,1

managerial implications are presented and finally conclusions are drawn, and recommendations are proposed in section seven.

\section{Theoretical background}

There is an increasing importance in a variety of building façade systems revealed as innovative products existing in the construction market (Sezegen and Edis, 2020). Designers are frequently determined by their vision involving aesthetics, visualization and functionality for creating dynamic building façades with restricted evaluation of performance measures solution. Dynamic building façades are generally categorized as responsive, transformable kinetic structures, utilizing innovative materials features and adaptive intelligent system (Mallasi, 2019). Façade components as transformed from passive technical outputs to active systems can primarily convert a building in a dynamic and adaptive system and generate renewable energy with spatial arrangements and behavior of its exterior coverings to enhance settings of interior comfort. By the existence of innovative materials and mechanized systems with various levels of complications, the building, thus, turns out to be a dynamic system, wherein each component responds to exterior and interior conditions, familiarizing to the environmental settings so as to regulate and optimize the total energy stability needed for its performing (Romano et al., 2018). Multi-functional, adaptive and dynamic façades can be considered the future significant breakthrough in façade technology. Adaptive building façades can act together with the ecosystem and the user by responding to exterior conditions, insulating merely if needed, generating energy if practicable, shading or ventilating whenever required to enhance indoor comfort and familiarizing the behavior and functionality consequently (Aelenei et al., 2015). Adaptive façades empower energy savings by acclimating to current climate settings and sustain comfort levels by instantaneously reacting to inhabitants' requirements and choices (Loonen et al., 2013). Therefore, adaptability is recognized as a system capability to provide desired practicality, contemplating multiple criteria in varying circumstances, due to the factors of design altering the tangible assesses throughout time (Ferguson et al., 2007).

Adaptive façades have to deliver an acceptable response to variations in the interior and exterior conditions to maintain or enhance the operational needs of the building skin as per the solar heat, rain penetration, flow of air and water vapor, strength and stability, fire, noise and aesthetics. Consequently, multi-functional adaptive façades must be able to react continually and conversely over the years to variations in functional conditions and changing environmental circumstances. Adaptive façades must be capable of providing controllable thermal mass and insulation, energy collecting, lucent heat exchange, daylighting, solar shading, ventilation or humidity control (Aelenei et al., 2016).

The adaptive façades recently constructed in various terrestrial zones are qualified by the supportive attribute of the building technologies, and the existence of by-laws and directives formulates them a crucial component in the complex building system (Romano et al., 2018). High performance adaptive façade system models are presented in Table 1.

Due to the inherent complexity of the dynamic performances of the adaptive façade systems, methods for simulations and experiments and consistent evaluation criteria are yet progressing. Consequently, researchers are actively involved in the description of the required standardized methods that are able to assist the accomplishments of adaptive facades in buildings (Favoino et al., 2018).

\section{Analytic network process}

The methodology employed in this research for evaluation of the performance of adaptive façade systems in complex commercial buildings encompasses application of ANP. The ANP 
Adaptive façade

system

Active façades (ACFs)

Advanced façades (ADFs)

Biomimetic or bioinspired saçades (BIFs)

Kinetic Façades (KFs)

Intelligent façades (ITFs)

Interactive façades (IRFs)

Movable façades (MFs)
Description self-adjust to changes commenced by the internal or external building environments, accomplishing comfort conditions whereas minimizing energy consumptions

Outer, weather-protecting layer of a building that can provide heating, cooling, ventilation and lighting requirements and support interior comfort through efficient, energy saving measures

Phototropism (i.e. changing in response to light) and heliotropism (i.e. changing in response to the sun) utilized in the climate adaptive building shells concepts that facilitate the active collection or rejection of solar energy

Involving a particular type of motion and being able to guarantee variable locations or mobility and/or variable geometry to all or one of its parts and designating an organism's response to a specific kind of stimulus in biology and an ability to control energy in its primary arrangements: visible light and heat Responding to climatic changes through the automatic reconfiguration of its systems, changing itself through "instinctive autonomic adjustment", optimizing the integrated building's systems relative to climate, energy balance and human comfort, typically based on predictive models Requiring human input to initiate a response, equipped with sensors and an automated building management system and programmed to optimize energy conservation whereas concurrently ensuring the comfort of its residents Rapidly adapting to the environmental conditions and location, the opening elements as separate parts of adaptable enclosures are equipped with photovoltaic elements tracking and following the position of the sun and producing renewable energy
Reference

Ochoa and Capeluto (2008) and

Romano et al. (2018)

Adaptive façade systems

Van der Aa et al. (2011) and Romano et al. (2018)

Vermillion (2002), Loonen et al. (2015) and Romano et al. (2018)

De Marco Werner (2013), Loonen

(2010), Fox and Yeh (1999), Wang et al. (2012), Fortmeyer and Linn (2014) and Romano et al. (2018)

Knaack and Klein (2008), Masri (2015) and Velikov and Thün (2013)

Velikov and Thün (2013) and Romano et al. (2018)

Schumacher et al. (2010) and Romano et al. (2018)

Table 1

High performance (continued) 
ECAM

29,1
Adaptive façade

system Description Reference

Responsive façades (RFs)

\section{6}

Utilizing sensor networks and actuators to monitor the environment and automate control of operable building elements, moveable, operable, manually controlled elements of buildings, assist in sustaining a proper balance between optimum interior conditions and energy performance by reacting in a controlled and holistic manner to outdoor and indoor environment changes and to occupants' requirements and also including interactive features such as computational algorithms allowing the building system to self-adjust and learn over time

Smart façades (SMFs) Modifying the physical geometric features to adapt to changes in their environment by utilization of dynamic solar screenings, positioned as a second skin on new and existing buildings Integrating smart glasses and smart adaptive materials to control light and energy flows through glass façades Efficiently tuned to climatic conditions, different locations, changing operational needs or emergency circumstances from a compact to an expanded process and consisting of controlled, secure movements and resulting in a rigid structure
Transformable façades (TF)
Meagher (2015), Heiselberg et al. (2006), Kolodziej and Rak (2013), Velikov and Thün (2013) and Romano et al. (2018)

Velikov and Thün (2013), Brugnaro et al. (2014) and Romano et al. (2018)

Beevor (2010) and Romano et al. (2018)

Chloë (2016) and Romano et al. (2018)

Table 1.

Figure 1.

Stages of ANP method is a method developed by Saaty (1996) representing a network structure applied to model the criteria for the decision-making of complex subjects. The ANP considers the dependencies among determinants and utilizes the relations of aforesaid interdependencies. The ANP delivers a further realistic methodology to decision problems and an improved assessment (Yücelgazi and Yitmen, 2020). The ANP method comprises five main stages (Gür et al., 2016), as shown in Figure 1.

First, the issue investigated is thoroughly analyzed, the objectives are specified evidently and criteria are determined to assess the objectives. Through dividing the system into separate parts, the network structure of the decision problem is created. Second, to exactly clarify the structure of the problem that is separated to its parts, all interrelations between criteria are considered accordingly. Third, the criteria determined in the identified problem are evaluated by the relevant experts. Using Saaty's (1996) 1-9 scales, superiorities are determined by comparing the criteria with each other accordingly. Pairwise comparison
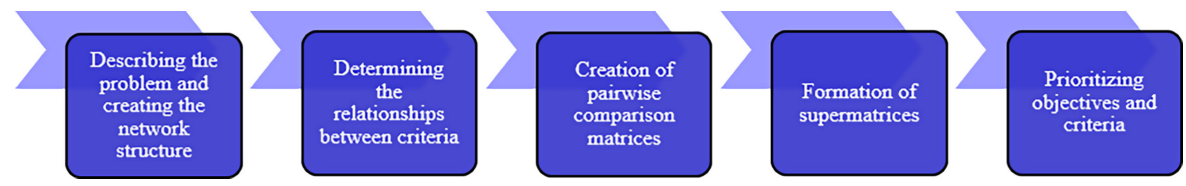
matrices are created by evaluating the criteria built on the relevant experts' viewpoints. Fourth, supermatrices comprising fragmented structures, into which the dependencies between the criteria are transferred, are created to facilitate in achieving the priorities with values of eigenvectors. Extracted eigenvectors are placed in unweighted supermatrix columns. Consequently, the sum of each column is normalized to create the weighted supermatrix. Decisively, to sort the priority weights values, the effect of the weighted super matrix is raised until they converge, and the new matrix acquired is named as the limit super matrix. Fifth, the resultant limit matrix exhibits the degree of importance of the compared objectives and criteria. The objectives and criteria are ranked in the order of priority.

\section{Analysis and results}

4.1 Implementation of ANP model for evaluating the performance of adaptive façade systems in complex commercial buildings

The method carried out in this study to create and implement an ANP model is indicated in Figure 2.

\subsection{Identification and categorization of high performance criteria for adaptive façade systems in complex commercial buildings}

Objective and criteria are identified on the basis of related literature studies, reports and data collected along with interviews and focus groups wherein the complete potential criteria are considered. In this research, the performance criteria for adaptive façade systems complex in commercial buildings were acquired from a literature analysis, as presented in Table 2 . The interviews were semistructured based on a literature review involving high performance criteria of adaptive façade systems. The interview questions primarily focused on validation of the multifunctional, dynamic and adaptive façade systems involving energy efficiency and environment, indoor comfort conditions, performance-related functions, maintenance and life cycle and adaptivity. The interview structure consisted of four main sections including background information and professional experience of the interviewees, definition of
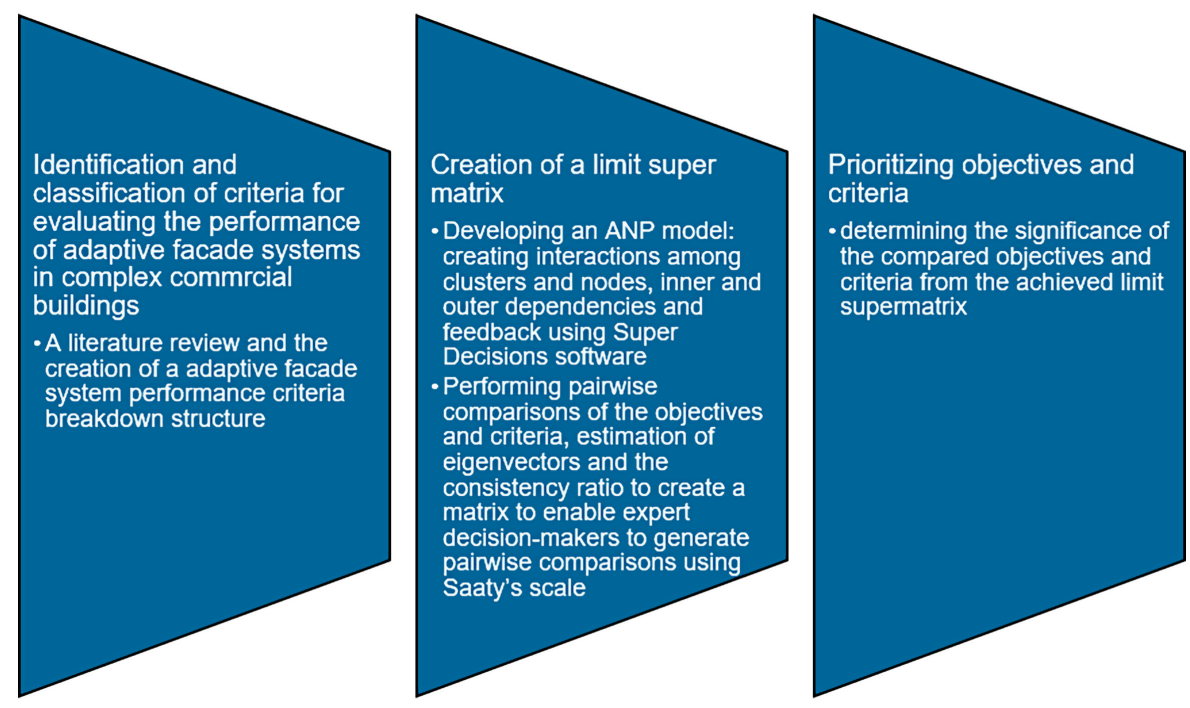

\section{Adaptive façade systems}

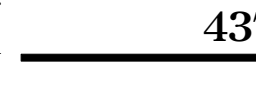


ECAM

29,1

High performance criteria of adaptive façade systems

Energy Indoor Performance-

efficiency and comfort related Maintenance

environment conditions functions and life cycle Adaptivity Previous study

438

Van de Aa et al. (2011),

Aelenei et al. (2016),

Ochoa and Capeluto

(2008), Loonen et al.

(2014) and Pierleoni et al. (2015)

Aelenei et al. (2016),

Loonen et al. (2014) and

Pierleoni et al. (2015)

Loonen et al. (2015),

Struck et al. (2015) and

Vermillion (2002)

Attia et al. (2018), De

Marco Werner (2013),

Fortmeyer and Linn

(2014), Hosseini et al.

(2019), Loonen (2010),

Fox and Yeh (1999),

Romano et al. (2018) and

Wang et al. (2012)

Attia et al. (2018),

Hosseini et al. (2019),

Knaack and Klein

(2008), Masri (2015),

Romano et al. (2018) and

Velikov and Thün

(2013)

Bakker et al. (2014),

Velikov and Thün

(2013)

Bakker et al. (2014) and

Schumacher et al. (2010)

Bakker et al. (2014),

Meagher (2015),

Heiselberg et al. (2006),

Kolodziej and Rak

(2013) and Velikov and

Thün (2013)

Attia et al. (2018),

Hosseini et al. (2019),

Velikov and Thün

(2013), Brugnaro et al.

(2014) and Romano et al. (2018)

Table 2.

Previous studies undertaken in the identification of high performance criteria of adaptive façade systems

Beevor (2010), Boeke et al. (2019) and Elzeyadi (2017)

Boeke et al. (2019), Chloë (2016) and Elzeyadi (2017) 
adaptive façade systems, advantages and performance indicators of adaptive façade systems and future of adaptive façade systems. Consequently, a questionnaire was distributed to producer and supplier companies specialized in adaptive façade systems for commercial buildings. The categorization of the respondents was done on the basis of their responsibilities and actions related with the projects. Table 3 shows the distributions of the respondents of the survey from different participating organizations and groups. A total of 120 completed questionnaires, as indicated in Table 3, were collected, providing a high response rate of $65 \%$. This shows that the procedure in sampling was efficient, and the participants understood the research to be applicable and meaningful. The contributors were requested to rate the significance of the objectives and criteria based on a five-point Likert scale of 1 (strongly disagree) to 5 (strongly agree).

Production managers, line managers, design managers, designers, project managers and construction managers were allocated ratings of significance based on the categorization of high performance criteria for adaptive façade systems. Figure 1 illustrates the average of these importance levels. A prominent level of similarity in high performance criteria of adaptive façade system was demonstrated by the responses of the various groups of participants as seen in Figure 3.

\begin{tabular}{llcr}
\hline Respondent & Position & Year of experience & Number/\% \\
\hline Producer & Production Manager & 16 & $9 / 7.5$ \\
& Line Manager & 12 & $12 / 10$ \\
& Design Manager & 11 & $12 / 10$ \\
& Designer & 10 & $15 / 12.5$ \\
Supplier & Project Manager & 15 & $15 / 12.5$ \\
& Construction Manager & 14 & $15 / 12.5$ \\
& Design Manager & 13 & $24 / 20$ \\
& Designer & 10 & $18 / 15$ \\
Total & & & $120 / 100$
\end{tabular}

Figure 3. Similarity of the importance given to the high performance criteria of adaptive façade system among the respondents 
ECAM

29,1

440

The nominal group technique (NGT) is applied to measure and rank viewpoints by confirming that group discussion to produce ideas occurs with a precise format. This admits prioritization of many viewpoints with mutual contribution (Kermanshachi et al., 2016). It supports the group of experts to accomplish consent by way of scoring. This procedure is favored as it enables rapid and shared decision-making among the participants. With respect to the priority rankings, high performance criteria were created by employing NGT with 20 experienced contributors. Table 4 quantitatively reveals the profile of qualified contributors, including Production Manager, Line Manager, Design Manager, Designer, Project Manager, Construction Manager, with the years of their experience.

Identification of high performance criteria of adaptive façade system process may lead to imprecise information if it is not performed correctly and accurately. Therefore, it is necessary to determine the relations between high performance criteria and transform them into a clear structure when acquiring high performance criteria. Consequently, as demonstrated in Figure 4, an adaptive façade system breakdown structure was created by

\begin{tabular}{|c|c|c|c|}
\hline Respondent & Position & Year of experience & Number $/ \%$ \\
\hline \multirow[t]{4}{*}{ Producer } & Production Manager & 15 & $2 / 10$ \\
\hline & Line Manager & 13 & $2 / 10$ \\
\hline & Design Manager & 10 & $3 / 15$ \\
\hline & Designer & 10 & $3 / 15$ \\
\hline \multirow[t]{4}{*}{ Supplier } & Project Manager & 14 & $2 / 10$ \\
\hline & Construction Manager & 13 & $2 / 10$ \\
\hline & Design Manager & 12 & $3 / 15$ \\
\hline & Designer & 10 & $3 / 15$ \\
\hline Total & & & $20 / 100$ \\
\hline
\end{tabular}

Table 4.

Focus groups participants' profile

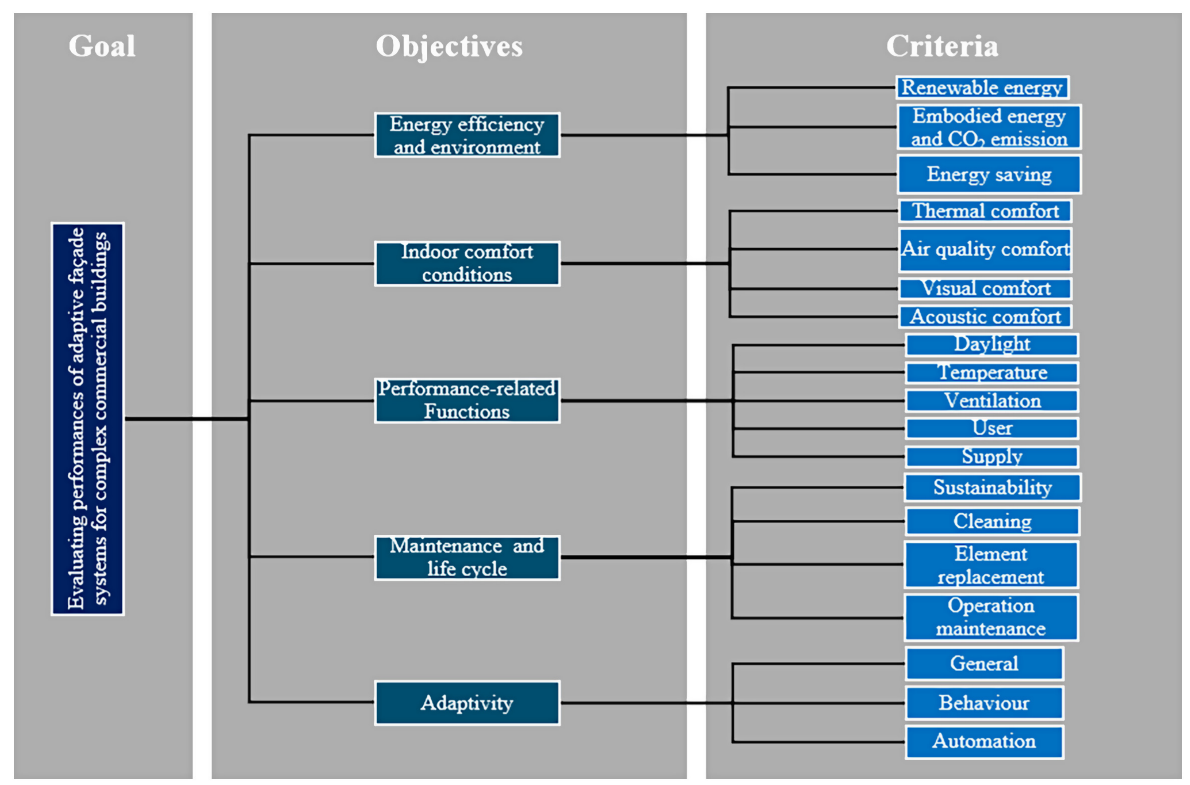

Figure 4.

Adaptive façade system breakdown structure 
separating the high performance criteria related with adaptive façade systems into five main objectives and setting criteria under each of these main objectives.

\subsection{The process of the developing the limit supermatrix}

The ANP method encompasses feedback and interdependence attributes. Hence, the criteria determined by external clusters (groups of performances of adaptive façade systems in each classification) can additionally be associated within themselves. Regarding the studies based on ANP, dependencies between clusters are known as external dependencies, and dependencies within clusters are named as internal dependencies. Furthermore, because the ANP approach encompasses mutual connections among the internal dependencies and the criteria, it secures more valuable and reasonable solutions in the decision-making phase (Görener, 2009). Considering the adaptive façade system breakdown structure achieved using Super Decisions software and the usage of connections between objectives and criteria including inner and outer dependencies, an ANP model was developed as demonstrated in Figure 5.

Afterward, comparison matrices were created and circulated to 40 expert decision-makers along with the Saaty's (1996) 1-9 scale. Table 5 indicates the profile of the respondents who completed pairwise comparisons. As illustrated, the respondents consist of production manager, line manager, design manager, designer, project manager and construction manager.

Table 6 illustrates a blank template of the comparison matrix to be filled in by the 40 experts involving the objectives "energy efficiency and environment". The experts were requested to fill in the blank fields applying the values of Saaty's ranking scale. For instance, regarding the objective "energy efficiency and environment" shown in Table 8, when the criterion "embodied energy and $\mathrm{CO}_{2}$ emission" is compared to the criterion "renewable energy", the value $1 / 8$, indicating that embodied energy and $\mathrm{CO}_{2}$ emission is very strong important than renewable energy. In this context, the geometric average of all the criteria rated by 40 experts was taken and reduced to objective tables. Values of scale shown in Tables 8-12 have been filled in accordingly. The calculation of eigen vectors is obtained by normalizing the paired comparison matrix and taking the average of each row. The main reason for calculating eigenvectors is to check the consistency of the comparison ratings. The maximum eigenvector is determined by multiplying the eigenvectors with the matrix size and taking the average of the eigenvector column. Afterward, the consistency ratios (CRs) are calculated by using the maximum eigenvectors to find the CI . If the consistency values are below 0.1 , they are considered sufficiently consistent; otherwise iterations are repeated if they exceed the threshold value.

Comparisons of the objectives and criteria achieved were exploited simultaneously in Super Decisions software to calculate the eigenvectors (order of priority) and CRs. CI is calculated by Equation (1):

$$
\mathrm{CI}=\frac{\lambda \max -n}{n-1}
$$

where $\lambda_{\max }$ is the largest eigenvalue, and $\mathrm{n}$ is the number of criteria.

$\mathrm{CI}$ is then used to calculate the CR, as seen in Equation (2):

$$
\mathrm{CR}=\frac{\mathrm{CI}}{\mathrm{RI}}
$$

Table 7 shows the random index (RI) values (Saaty, 1980).

In Table 8, the "embodied energy and $\mathrm{CO}_{2}$ emission" criterion has the highest significance with an eigenvalue of 0.707 . Simultaneously, the CR (0.05156) calculated on the line of the 
ECAM

29,1

Figure 5.

An ANP model developed for adaptive façade system

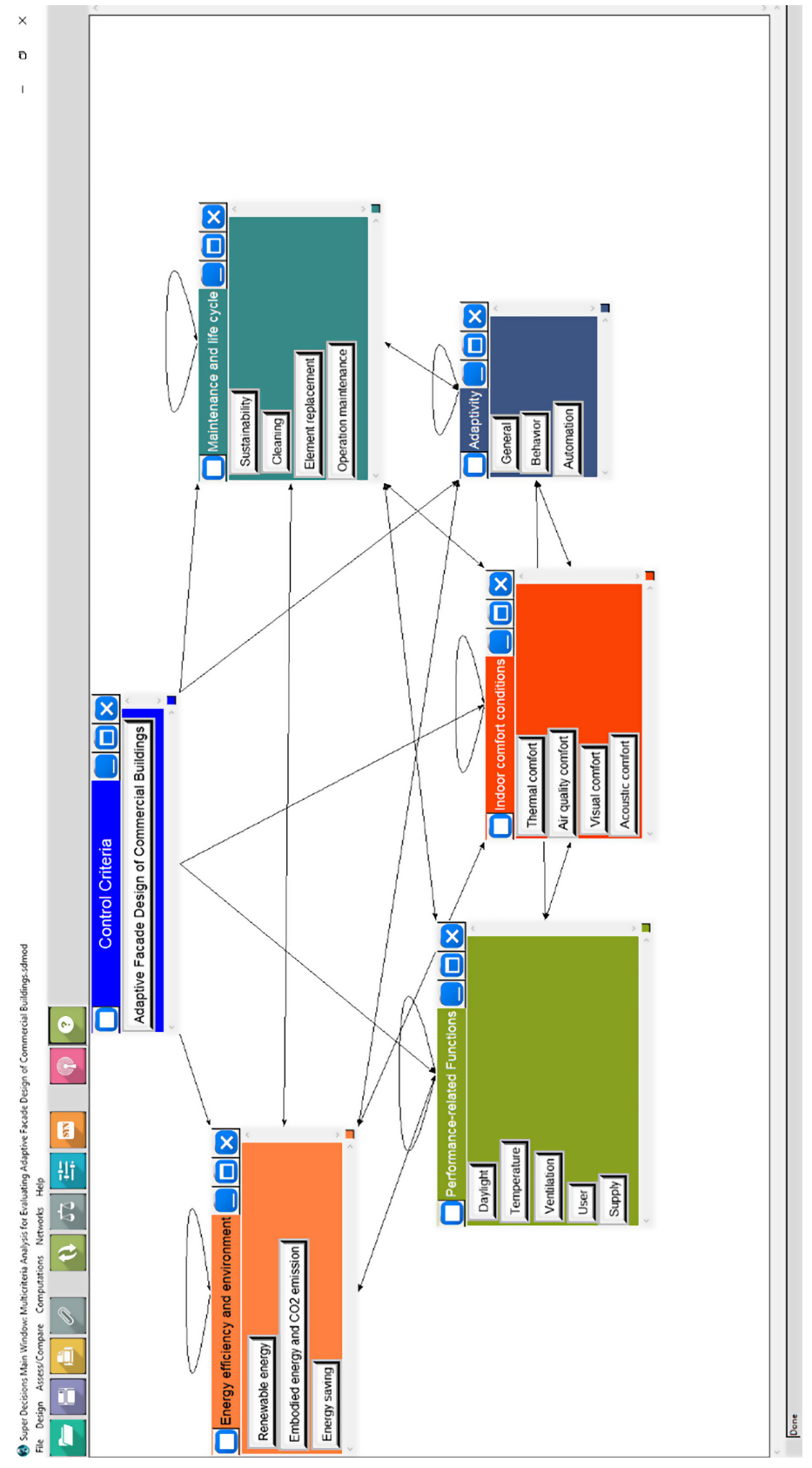


eigenvectors is below 0.1 and shows that it is sufficiently consistent. In Table 9 , the "thermal comfort" criterion has a high significance with an eigenvalue of 0.587 . Concurrently, the CR (0.03694) obtained in the light of eigenvectors shows that the rating made under indoor comfort conditions is sufficiently consistent. Table 10 indicates that the "daylight" criterion has a high significance with an eigenvalue of 0.516. In fact, the calculated consistency rate (0.08298) displays that the ratings made under performance-related functions are consistent. In Table 11, the "sustainability" criterion is of primary importance with an eigenvalue of 0.536. Certainly, the determined consistency value (0.09258) demonstrates that the comparison made under maintenance and life cycle is consistent. In Table 12 , "automation" is rated as the most important criterion with an eigenvalue of 0.695 .

\begin{tabular}{llcc}
\hline Respondent & Position & Year of experience & Number/\% \\
\hline Producer & Production Manager & 15 & $8 / 20$ \\
& Line Manager & 13 & $4 / 10$ \\
& Design Manager & 10 & $4 / 10$ \\
& Designer & 10 & $4 / 10$ \\
Supplier & Project Manager & 14 & $8 / 20$ \\
& Construction Manager & 13 & $4 / 10$ \\
& Design Manager & 12 & $4 / 10$ \\
& Designer & 10 & $4 / 10$ \\
Total & & & $40 / 100$
\end{tabular}

Table 5.

Pairwise comparison of respondents' profile

\begin{tabular}{lccc}
\hline & $\begin{array}{c}\text { Renewable } \\
\text { energy }\end{array}$ & $\begin{array}{c}\text { Embodied energy and } \mathrm{CO}_{2} \\
\text { emission }\end{array}$ & $\begin{array}{c}\text { Energy } \\
\text { saving }\end{array}$ \\
\hline $\begin{array}{l}\text { Renewable energy } \\
\text { Embodied energy and } \mathrm{CO}_{2}\end{array}$ & 1 & - & - \\
emission & $\mathbf{a}$ & 1 & - \\
Energy saving & $\mathbf{-}$ & $\mathbf{0}$ & 1
\end{tabular}

Note(s): $\square$ indicates not to be filled in; 1 indicates equal importance; - indicates Fill in by one of the numbers of the scale: $1 / 9,1 / 7,1 / 5,1 / 3,3,5,7$ and 9

- intermediate values $1 / 8,1 / 6,1 / 4,1 / 2,2,4,6$ and 8

Table 6.

A sample of pairwise comparison matrix presented to experts

\begin{tabular}{|c|c|c|c|c|c|c|c|c|c|c|c|c|c|c|c|c|}
\hline$N$ & 1 & 2 & 3 & 4 & 5 & 6 & 7 & 8 & 9 & 10 & 11 & 12 & 13 & 14 & 15 & Table 7 \\
\hline RI & 0 & 0 & 0.58 & 0.90 & 1.12 & 1.24 & 1.32 & 1.41 & 1.45 & 1.49 & 1.51 & 1.48 & 1.56 & 1.57 & 1.59 & values (Saaty, 1980) \\
\hline
\end{tabular}

\begin{tabular}{lccccc}
\hline & $\begin{array}{c}\text { Renewable } \\
\text { energy }\end{array}$ & $\begin{array}{c}\text { Embodied energy and } \mathrm{CO}_{2} \\
\text { emission }\end{array}$ & $\begin{array}{r}\text { Energy } \\
\text { saving }\end{array}$ & Eigenvector & \\
\hline $\begin{array}{l}\text { Renewable energy } \\
\text { Embodied energy and } \mathrm{CO}_{2}\end{array}$ & 1 & $1 / 8$ & $1 / 4$ & 0.070 & $\begin{array}{r}\text { Table 8. } \\
\text { emission }\end{array}$ \\
$\begin{array}{l}\text { Energy saving } \\
\text { Note(s): Consistency ratio (CR) }=0.05156\end{array}$ & 1 & 4 & 0.707 & $\begin{array}{r}\text { Pairwise comparison } \\
\text { regarding energy } \\
\text { efficiency and } \\
\text { environment }\end{array}$ \\
\hline
\end{tabular}


ECAM

29,1

444

Concurrently, the consistency value obtained proves the consistency of the rating made under adaptivity. Table 13 illustrates a cross section of the limit supermatrix (priority values) obtained in the Super Decision software. Parallel to this, Table 14 represents the priority values as collectively and as percentages.

The results of CRs were examined to validate that they were below 0.1. Among all pairwise comparisons that were made, displayed in Tables 8-12. Following the application of pairwise comparisons and confirmation of CRs, the Super Decisions software is performed to acquire the limit supermatrix for achieving the high performance criteria sorted in the priority order. Table 13 represents a section of the limit super matrix that was acquired.

\begin{tabular}{|c|c|c|c|c|c|}
\hline & $\begin{array}{l}\text { Thermal } \\
\text { comfort }\end{array}$ & $\begin{array}{l}\text { Air quality } \\
\text { comfort }\end{array}$ & $\begin{array}{l}\text { Visual } \\
\text { comfort }\end{array}$ & $\begin{array}{l}\text { Acoustic } \\
\text { comfort }\end{array}$ & Eigenvector \\
\hline Thermal comfort & 1 & 6 & 3 & 8 & 0.587 \\
\hline $\begin{array}{l}\text { Air quality } \\
\text { comfort }\end{array}$ & $1 / 6$ & 1 & $1 / 3$ & 3 & 0.108 \\
\hline Visual comfort & $1 / 3$ & 3 & 1 & 5 & 0.251 \\
\hline Acoustic comfort & $1 / 8$ & $1 / 3$ & $1 / 5$ & 1 & 0.051 \\
\hline \multicolumn{6}{|c|}{ Note(s): Consistency ratio $(\mathrm{CR})=0.03694$} \\
\hline
\end{tabular}

Table 9.

Pairwise comparison regarding indoor comfort conditions

\begin{tabular}{lcccccc}
\hline & Daylight & Temperature & Ventilation & User & Supply & Eigenvector \\
\hline Daylight & 1 & 6 & 3 & 8 & 9 & 0.516 \\
Temperature & $1 / 6$ & 1 & $1 / 3$ & 6 & 6 & 0.138 \\
Ventilation & $1 / 3$ & 3 & 1 & 8 & 9 & 0.272 \\
User & $1 / 8$ & $1 / 6$ & $1 / 8$ & 1 & 2 & 0.041 \\
Supply & $1 / 9$ & $1 / 6$ & $1 / 9$ & $1 / 2$ & 1 & 0.030 \\
Note(s): Consistency ratio (CR) & $=0.08298$ & & & & \\
\hline
\end{tabular}

\begin{tabular}{lccccc}
\hline & Sustainability & Cleaning & $\begin{array}{c}\text { Element } \\
\text { replacement }\end{array}$ & $\begin{array}{c}\text { Operation } \\
\text { maintenance }\end{array}$ & Eigenvector \\
\hline $\begin{array}{l}\text { Sustainability } \\
\text { Cleaning }\end{array}$ & 1 & 4 & 9 & 3 & 0.536 \\
$\begin{array}{l}\text { Element } \\
\text { replacement }\end{array}$ & $1 / 4$ & 1 & 7 & $1 / 3$ & 0.144 \\
$\begin{array}{l}\text { Operation } \\
\text { maintenance }\end{array}$ & $1 / 3$ & $1 / 7$ & 1 & $1 / 9$ & 0.034 \\
Note(s): Consistency ratio (CR) $=0.09258$ & 3 & 9 & 1 & 0.284 \\
\end{tabular}

Table 10.

Pairwise comparison regarding performance-related functions

Note(s): Consistency ratio $(\mathrm{CR})=0.08298$

\section{Table 11}

Pairwise comparison regarding maintenance and life cycle

\begin{tabular}{lcccc}
\hline & General & Behavior & Automation & Eigen vector \\
\hline General & 1 & $1 / 4$ & $1 / 7$ & 0.075 \\
Behavior & 4 & 1 & $1 / 4$ & 0.229 \\
Automation & 7 & 4 & 1 & 0.695 \\
Note(s): Consistency ratio (CR) $=0.07348$ & & & \\
\hline
\end{tabular}




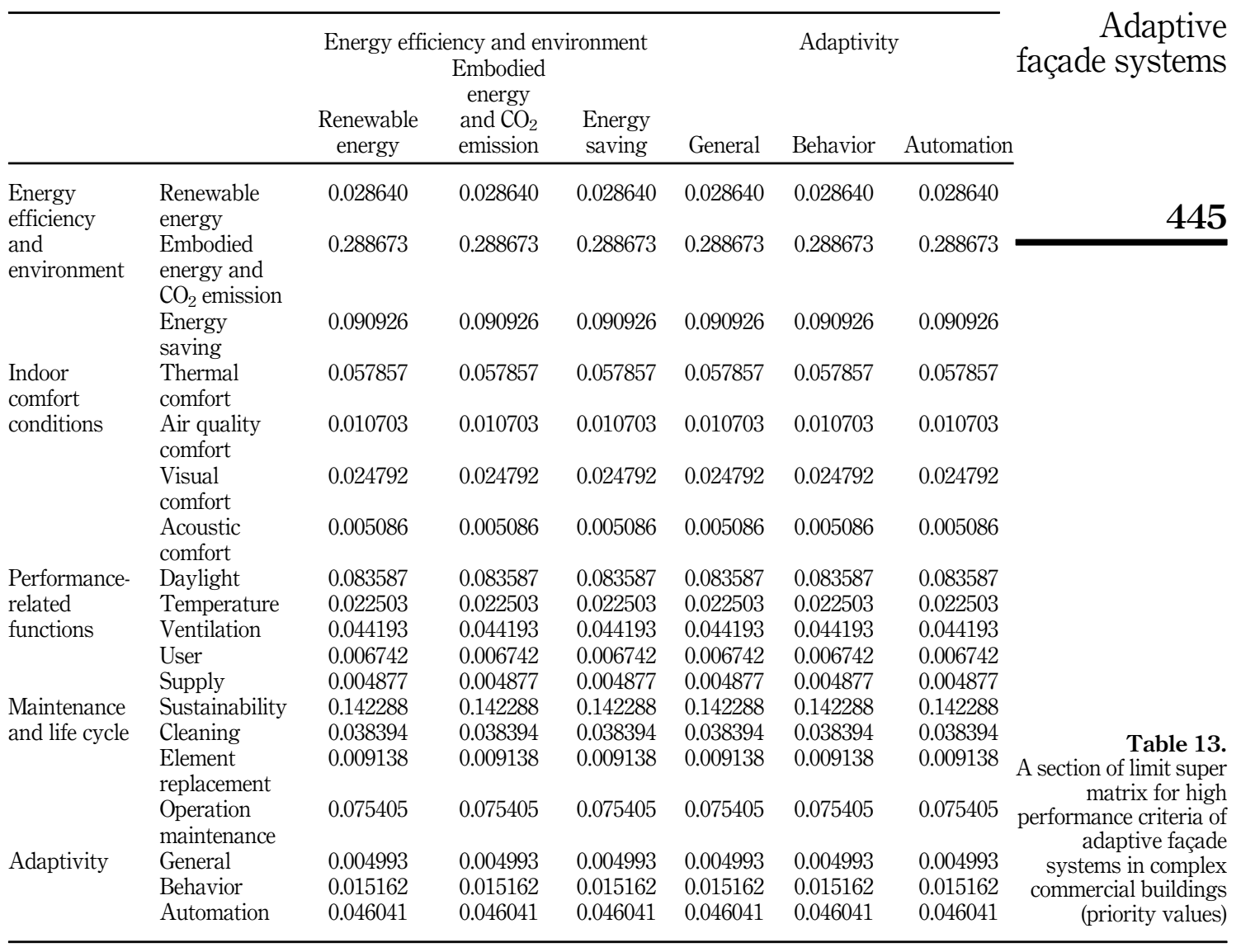

\section{Discussion of results}

The values obtained in Table 14 reveal that the most significant high performance criteria are listed in energy efficiency and environment and maintenance and life cycle categories. The first two important criteria signifying the "embodied energy and $\mathrm{CO}_{2}$ emission" and "sustainability" display the priority values of 28.87 and $14.23 \%$, respectively. The results are congruent with the recent previous studies (Azari and Abbasabadi, 2018; Crespi and Persiani, 2019) supporting the contention that the amount of embodied energy is anticipated to increase with the growing number of low energy buildings that reduce their operational energy at the distribution of a rise in their embodied energy through the integration of active and passive technologies and building systems (Azari and Abbasabadi, 2018). Based on the requirements for optimization of operational energy in buildings that the theme of adaptive facades has created a significant form of technological solutions encouraging for higher comfort conditions while reducing energy use. Adaptive façade systems are characterized by their specific functioning and considered of energy efficiency signifying views of the system's real sustainability. Embodied energy and $\mathrm{CO}_{2}$ emission of the system is extremely interesting as a result of its potential to reduce the environmental impacts on the usage phase (Crespi and Persiani, 2019).

The third high performance criterion is "energy saving" having the priority value of $9.09 \%$. The results are consistent with the recent previous studies (Tabadkani et al., 2020a, b; 


\begin{tabular}{lllrr} 
ECAM & Objectives & Criteria & Priority & Priority \% \\
\cline { 2 - 5 } 29,1 & Energy efficiency and environment & Embodied energy and $\mathrm{CO}_{2}$ emission & 0.28867 & 28.87 \\
& Maintenance and life cycle & Sustainability & 0.14229 & 14.23 \\
& Energy efficiency and environment & Energy saving & 0.09093 & 9.09 \\
& Performance-related functions & Daylight & 0.08359 & 8.36 \\
& Maintenance and life cycle & Operation maintenance & 0.07541 & 7.54 \\
$\mathbf{4 4 6}$ & Indoor comfort conditions & Thermal comfort & 0.05786 & 5.79 \\
& Adaptivity & Automation & 0.04604 & 4.60 \\
& Performance-related functions & Ventilation & 0.04419 & 4.42 \\
& Maintenance and life cycle & Cleaning & 0.03839 & 3.84 \\
& Energy efficiency and environment & Renewable energy & 0.02864 & 2.86 \\
& Indoor comfort conditions & Visual comfort & 0.02479 & 2.48 \\
& Performance-related functions & Temperature & 0.02250 & 2.25 \\
& Adaptivity & Behavior & 0.01516 & 1.52 \\
& Indoor comfort conditions & Air quality comfort & 0.01070 & 1.07 \\
& Maintenance and life cycle & Element replacement & 0.00914 & 0.91 \\
Table 14. & Performance-related Functions & User & 0.00674 & 0.67 \\
Priority orders & Indoor comfort conditions & Acoustic comfort & 0.00509 & 0.51 \\
& Adaptivity & General & 0.00499 & 0.50 \\
& Performance-related functions & Supply & 0.00488 & 0.49
\end{tabular}

Bui et al., 2020; Albag et al., 2020) supporting the view that adaptive façade systems include building envelopes, which can manage occupant's visual and thermal comfort along to increase energy savings (Tabadkani et al., 2020a, b). Adaptive façade systems are reflected as a probable solution to improve the energy efficiency of buildings (Bui et al., 2020). Adaptive façade systems, utilizing stimulus-responsive materials and smart handling systems, can transform in response to environmental settings, consequently increasing inhabitants' comfort and improving energy savings (Albag et al., 2020).

The fourth high performance criterion is "daylight" having the priority value of $8.36 \%$. The results are coherent with the recent previous studies (Bui et al., 2020; Cheong et al., 2020; Loonen et al., 2013; Tabadkani et al., 2020a, b) supporting the argument that the changes of climatic condition, i.e. daylight, cause major challenges to the performance of an adaptive façade system for net zero energy buildings (nZEB) (Bui et al., 2020). Specifically, in office buildings, it is crucial to ensure effective daylighting systems to control undesirable solar gains and discomfort brightness, whilst counteracting electrical lighting loads (Cheong et al., 2020). Building façades have to be adaptive to short-time weather variations, daily cycles or seasonal repetitions and have the ability to compensate aggressive performance criteria of indoor environment of inhabitants to accomplish enhanced performance contrasted to static shading systems (Loonen et al., 2013). Hence, adaptive façade systems can maintain the stability between the daylight collecting and maximizing outdoor view while reducing visual discomfort and energy load of building (Tabadkani et al., 2020a, b).

The fifth high performance criterion is "operation maintenance" having the priority value of $7.54 \%$. The results are accordant with the recent previous studies (Loonen et al., 2015; Aresta, 2017; Santos et al., 2020; Attia et al., 2018) supporting the opinion that adaptive facade systems function in inherent manner that is capable of self-setting; subsequently, the adaptive performance is routinely stimulated by environmental incentives (Loonen et al., 2015), requiring no processors or external power (Aresta, 2017), thereby allows low-cost operation and maintenance (Loonen et al., 2015; Santos et al., 2020). Smart and predictive maintenance can ensure adaptive façade systems' vigorous performance and their liability (Attia et al., 2018). 
The sixth high-performance criterion is "thermal comfort" having the priority value of $5.79 \%$. The results are congruent with the recent and previous studies (Altomonte et al., 2019; Pastore and Anderson, 2019) supporting the contention that evaluating comfort and inhabitants' satisfaction is an increasing concern in adaptive façade systems, as growing appreciation of the significance of comfort of inhabitants in office buildings. Thermal comfort is one of the firmest discern of comfort and satisfaction of inhabitants in buildings (Altomonte et al., 2019; Pastore and Anderson, 2019).

The seventh high-performance criterion is "automation" having the priority value of $4.60 \%$. The results are consistent with the recent and previous studies (Dominges et al., 2016; Boeke et al., 2019; Böke et al., 2020; Attia, 2018) supporting the view that automation currently performs a critical role in facility management of buildings. Building automation systems (BASs) operate, monitor and control numerous features of building services to ensure the interior comfort while saving energy (Domingues et al., 2016). The related intelligent assistance of automated adaptive façade operations, stimulated by intelligent technological systems in Industry 4.0, suggests a prospective for the total building performance (Böke et al., 2020). A tool for evaluating the automated adaptive application of specific façade operations based on predescribed attributes was presented (Boeke et al., 2019). Adaptive façade comprising automated dynamic solar screen reacts dynamically and automatically to the angle of the sun, thereby enhances the control of energy consumption, solar radiation and brightness with the capacity to permit natural light into the building (Attia, 2018).

The eighth high performance criterion is "ventilation" having the priority value of $4.42 \%$. The results are coherent with the recent previous studies (Iommi, 2018; Sánchez et al., 2020) supporting the argument that an air gap is created for the adaptive façade module to adjust the energy efficiency, provide a ventilated façade or increase the thickness insulation content if necessary (Iommi, 2018). Ventilated façades are very commonly utilized passive components unified inside to buildings, specifically to minimize these loads. This decrease is as a result of the airflow generated in the air chamber through the resilience forces, as the solar waves warm the external tier of the façade (Sánchez et al., 2020). The ventilated façades are described primarily through the existence of a ventilated conduit built among the interior and exterior layers of the building façade. An effective design of these approaches must thoroughly contemplate operational and implementation involvements, along with aesthetic options and architectural concerns.

The ninth high performance criterion is "cleaning" having the priority value of $3.83 \%$. The results are accordant with the recent and previous studies (Sandak et al., 2019; Romano et al., 2021) supporting the opinion that as the requirement for building maintenance is rising, automated building façade cleaning has turned out to be vital. Distinctive adaptation solutions can be employed in innovative materials, which are utilized in building façade built in certain climate zones. The optimization process is supposed to stimulate the advancement of active biomaterials acting as interfaces between outside settings and interior comfort that are capable to balance and coordinate self-clean and self-heal (Sandak et al., 2019; Romano et al., 2021).

The tenth high performance criterion is "renewable energy" having the priority value of $2.86 \%$. The results are congruent with the recent and previous studies (Perino and Serra, 2015) supporting the contention that adaptive façade systems can achieve significant improvement in energy efficiency and in encouraging the usage of renewable energy in the built environment. The components in these adaptive façade systems can constantly and proactively respond to outdoor and indoor environment conditions and enable and improve the utilization of renewable and low energy sources (Periono and Serra, 2015).

The eleventh high performance criterion is "visual comfort" having the priority value of $2.48 \%$. The results are consistent with the recent and previous studies (Michael et al., 
ECAM

29,1

448

2018; Tabadkani et al., 2019) supporting the view that the adaptive façade systems enable the enhancement of the visual comfort conditions of the buildings' inhabitants through optimization of natural lighting performance and the reduction of glare problems, together with the minimization of energy consumption of the building produced by the usage of artificial lighting (Michael et al., 2018). There is the necessity of adaptive solar façade systems allowing adaptability to climate change and having capability of optimized visual comfort (Tabadkani et al., 2019). A hexagonal adaptive system to accomplish the highest visual comfort level based on the inhabitants' preferences that can be the foundation for potential asset on smart building envelopes was presented.

The twelfth high performance criterion is "temperature" having the priority value of $2.25 \%$. The results are coherent with the recent and previous studies (Böke et al., 2020; Rizi and Entawel, 2021; Hosseini et al., 2019) supporting the argument that adaptive façade systems involve the automated control of blinds reliant on the outdoor temperature, amount of light and wind speeds and revealed that optimized adaptive shadings reduce the heat gain due to high temperature at significant levels (Rizi and Entawel, 2021). Kinetic façade systems adapt microclimate in an ecological environment by regulating airflow, solar radiation throughout the facade body causing in modifying surfaces temperature of the building close to the interior spaces (Hosseini et al., 2019).

This study is unique in terms of implementing the ANP method for evaluating the comprehensively compiled objectives and high performance criteria of adaptive façade systems. Performing such quantitative and qualitative evaluations of the explored wide domain of design parameters for adaptive façade systems will contribute to the development of a generative design approach in a multi-disciplinary platform. The presented approach will encourage cumulativity and divergent thinking and facilitate functional decomposition of performance criteria in the design of adaptive façade systems for complex buildings.

\section{Managerial implications}

This research primarily provides the required actions and evaluations for design managers in accomplishing a high performance adaptive façade system by utilizing an ANP method. In developing a systematic decision-making process, the design managers can primarily describe adaptive façade system goals, objectives, criteria and limitations. Before beginning the adaptive façade system of a building design procedure, the design manager should decide on the significance of each of these criteria since high performance priorities will affect the determinations during the overall design procedure. For this purpose, design managers need to compare the high performance criteria. The ANP model signifies the interdependencies of high performance goals, objectives and criteria in detail. Pairwise comparison values of CRs and limit super matrices acquired through Super Decisions. Pairwise comparisons facilitated the order of the priorities between criteria. Validity of the comparisons is tested by consistency indices. Priority values of the high performance criteria are exposed by the limit supermatrix; moreover, the comparisons of criteria priority orders are unambiguously expressed. This ANP model could attract attention of design managers of producer and supplier firms. The findings achieved through presented research could be provided as a guideline and promote the evaluation of potential adaptive façade systems. Additionally, the findings could be applied to contrast and differentiate the priority orders of high performance criteria for evaluating adaptive façade systems forthcoming MCDM research studies and verify alterations. This ANP model accomplishes encouraging consequences for evaluation of high performance criteria in planning and designing phases of adaptive façade systems in complex commercial buildings. 
The ANP method implemented in this study can contribute to the design of multifunctional, dynamic and adaptive façade systems. A comprehensive understanding of the function and technological solutions for the building envelope are provided for the designers. Designers will be aware of these technologies to be enabled to effectively design better and support industry to develop sustainable solutions. Such systems could be used as responsive and dynamic building elements and contribute to an improved performance and energy efficiency of building envelope. A sample of a design criteria assessment for the performance of adaptative façade systems is illustrated in Table 15. The criteria and associated objectives, behavior/action and benefits of each of them are specified. It is worth to note that prioritized criteria have their own objectives and goals regarding the performance of the type of adaptive façade system under consideration. Design managers can use the prioritized criteria as an executive tool for the systematic assessment of adaptive façade functions in accomplishing building envelopes to analyze the technical basis for implementation. This systematic assessment of adaptive façade functions could contribute to the designers' parametric design thinking approaches facilitating quantitative and qualitative evaluations, combining many design variants and diverse methods and creating a multidisciplinary platform for exploring wide domain of design varieties. Such generative design approach is generally aimed at improving the indoor environmental quality, at facilitating the exploitation of renewable energy sources at the building scale and can involve novel / smart materials or an extension of specific principles (like bio-mimetic and naturebased concepts) for building enclosures.

\begin{tabular}{|c|c|c|c|c|}
\hline Criteria & Objectives & Behavior/Action & Benefits & \\
\hline $\begin{array}{l}\text { Embodied energy } \\
\text { and } \mathrm{CO}_{2} \text { emission }\end{array}$ & $\begin{array}{l}\text { Energy efficiency } \\
\text { and environment }\end{array}$ & $\begin{array}{l}\text { Integration of active and passive } \\
\text { technologies }\end{array}$ & Reduced operational energy & \\
\hline Sustainability & $\begin{array}{l}\text { Maintenance and } \\
\text { life cycle }\end{array}$ & $\begin{array}{l}\text { Minimizing operational } \\
\text { maintenance }\end{array}$ & Reduced life cycle costs & \\
\hline Energy saving & $\begin{array}{l}\text { Energy efficiency } \\
\text { and environment }\end{array}$ & $\begin{array}{l}\text { Optimization of heating and } \\
\text { cooling loads }\end{array}$ & $\begin{array}{l}\text { Reduced energy } \\
\text { consumption }\end{array}$ & \\
\hline Daylight & $\begin{array}{l}\text { Performance- } \\
\text { related functions }\end{array}$ & $\begin{array}{l}\text { Maintaining the stability } \\
\text { between daylight collecting and } \\
\text { maximizing outdoor view }\end{array}$ & $\begin{array}{l}\text { Reduced visual discomfort } \\
\text { and energy load of building }\end{array}$ & \\
\hline $\begin{array}{l}\text { Operation } \\
\text { maintenance }\end{array}$ & $\begin{array}{l}\text { Maintenance and } \\
\text { life cycle }\end{array}$ & $\begin{array}{l}\text { Ensuring smart and predictive } \\
\text { maintenance }\end{array}$ & $\begin{array}{l}\text { Low-cost and vigorous } \\
\text { performance }\end{array}$ & \\
\hline Thermal comfort & $\begin{array}{l}\text { Indoor comfort } \\
\text { conditions }\end{array}$ & $\begin{array}{l}\text { Controlling solar radiation and } \\
\text { maintaining comfortable } \\
\text { operative temperatures }\end{array}$ & $\begin{array}{l}\text { Ensured comfort level of } \\
\text { indoor environment }\end{array}$ & \\
\hline Automation & Adaptivity & $\begin{array}{l}\text { Reacting dynamically and } \\
\text { automatically to environmental } \\
\text { conditions }\end{array}$ & $\begin{array}{l}\text { Automated and adaptive } \\
\text { façade operations }\end{array}$ & \\
\hline Ventilation & $\begin{array}{l}\text { Performance- } \\
\text { related functions }\end{array}$ & $\begin{array}{l}\text { Regulating vigorously the air- } \\
\text { flow intake under suitable } \\
\text { weather conditions }\end{array}$ & $\begin{array}{l}\text { Utilized low energy or } \\
\text { passive components to } \\
\text { minimize energy loads }\end{array}$ & \\
\hline Cleaning & $\begin{array}{l}\text { Maintenance and } \\
\text { life cycle }\end{array}$ & $\begin{array}{l}\text { Active biomaterials acting as } \\
\text { interfaces between outside } \\
\text { settings and interior comfort }\end{array}$ & $\begin{array}{l}\text { Balanced and coordinated } \\
\text { self-clean and self-heal }\end{array}$ & \\
\hline Renewable energy & $\begin{array}{l}\text { Energy efficiency } \\
\text { and environment }\end{array}$ & $\begin{array}{l}\text { Constantly and proactively } \\
\text { responding to outdoor and indoor } \\
\text { environment conditions }\end{array}$ & $\begin{array}{l}\text { Enabled and improved } \\
\text { utilization of renewable and } \\
\text { low energy sources }\end{array}$ & $\begin{array}{r}\text { Table } 15 . \\
\text { A sample of a design } \\
\text { criteria assessment for }\end{array}$ \\
\hline Visual comfort & $\begin{array}{l}\text { Indoor comfort } \\
\text { conditions }\end{array}$ & $\begin{array}{l}\text { Optimization of natural lighting } \\
\text { performance and the reduction of } \\
\text { glare problems }\end{array}$ & $\begin{array}{l}\text { Enhanced lighting levels } \\
\text { and visibility to the outer } \\
\text { environment }\end{array}$ & $\begin{array}{r}\text { the performance of } \\
\text { adaptative façade } \\
\text { systems }\end{array}$ \\
\hline
\end{tabular}


ECAM

29,1

\section{Conclusions and recommendations}

Several fields and information sources are included in the decision-making procedure of evaluating performances of adaptive façade systems for complex commercial buildings. The multi-disciplinary character of adaptive façade systems, besides the need for the necessity for ensuring high-performance criteria, lead the decision-making process to turn out to be significantly complex. This complexity is more evident during the evaluation of the entire essential high-performance criteria that may be mutually contradictory. Consequently, a comprehensive method is required to evaluate the high performance criteria of adaptive façade systems in complex commercial buildings.

In this research, a relatively innovative, systematic and practical method is suggested to support the decision-making process for evaluation of the high performance criteria of adaptive façade systems in complex commercial buildings. For this purpose, major goals, objectives as well as criteria, which compose a high performance adaptive façade system, were identified, and the design managers were procured with a collaborative and comprehensive guidance for the evaluation of adaptive façade system that defines the considerations required for high performance criteria.

A prevalent literature review was primarily performed to identify the high performance criteria for evaluation of adaptive façade systems. Congruently, explanatory sessions with competent specialists were organized, and a hierarchical adaptive façade system breakdown structure was developed. With the hierarchical adaptive façade system breakdown structure, the Super Decisions software was employed for the application of an ANP model. The pairwise comparisons acquired through the ANP model were accomplished in collaboration with competent specialists in adaptive façade systems. The limit supermatrix was achieved to obtain the orders of priority for high performance criteria employing pairwise comparison matrix values in the Super Decisions software. Embodied energy and $\mathrm{CO}_{2}$ emission, sustainability, energy saving, daylight and operation maintenance were acknowledged as the most significant high performance criteria for adaptive façade systems in complex buildings.

Though this research suggested a variety of prospects for future research, it has limitations as well. First, the objectives and criteria identified for evaluation were constrained. Second, objectives and criteria were limited to complex commercial buildings. Third, this research focused on the high performance criteria of adaptive façade systems challenged during planning and design phases. For future studies, it could be investigated to what extent the determined high performance criteria have a major influence on total building performance and the comfort level of inhabitants.

\section{References}

Aelenei, L., Brzezicki, M., Knaack, U., Luible, A., Perino, M. and Wellershoff, F. (2015), "COST action TU1403 - adaptive facades network”, in Aelenei, L., Brzezicki, M., Knaack, U., Luible, A., Perino, M. and Wellershoff, F. (Eds), Adaptive Façade Network - Europe, TU Delft Open, Delft.

Aelenei, D., Aelenei, L. and Pacheco Vieira, C. (2016), “Adaptive Façade : concept, applications, research questions", SHC 2015, International Conference on Solar Heating and Cooling for Buildings and Industry, Energy Procedia, Vol. 91, pp. 269-275.

Albag, O., Anishchenko, M., Grassi, G. and Paoletti, I. (2020), "Adaptive skins: towards new material systems", Digital Transformation of the Design, Construction and Management Processes of the Built Environment, Springer, Cham, pp. 209-219.

Altomonte, S., Schiavon, S., Kent, M.G. and Brager, G. (2019), "Indoor environmental quality and occupant satisfaction in green-certified buildings", Building Research and Information, Vol. 47 No. 3, pp. 255-274. 
Aresta, C. (2017), "Auto-reactive strategies. A catalogue of materials for innovative façade components", Proceedings of the International Mid-term Conference of the European COST Action TU1403 Adaptive Façade Network, Munich, Germany, TUM, pp. 16-17.

\section{Adaptive façade systems}

Atmaca, E. and Basar, H.B. (2012), "Evaluation of power plants in Turkey using analytic network process (ANP)", Energy, Vol. 44 No. 1, pp. 555-563.

Attia, S. (2018), "Evaluation of adaptive facades: the case study of Al Bahr Towers in the UAE", QScience Connect, 2017 (2, Special Issue on Shaping Qatar's Sustainable Built EnvironmentPart I), p. 6.

Attia, S., Bilir, S., Safy, T., Struck, C., Loonen, R. and Goia, F. (2018), "Current trends and future challenges in the performance assessment of adaptive façade systems", Energy and Buildings. doi: 10.1016/j.enbuild.2018.09.017.

Azari, R. and Abbasabadi, N. (2018), "Embodied energy of buildings: a review of data, methods, challenges, and research trends", Energy and Buildings, Vol. 168, pp. 225-235, doi: 10.1016/j. enbuild.2018.03.003.

Bakker, L.G., Oeffelen, E.C.M.H., Loonen, R.C.G.M. and Hensen, J.L.M. (2014), "User satisfaction and interaction with automated dynamic facades: a pilot study", Building and Environment, Vol. 78, pp. 44-52, doi: 10.1016/j.buildenv.2014.04.007.

Balcomb, J.D. and Curtner, A. (2000), "Multi-criteria decision-making process for buildings", Collection of Technical Papers. 35th Intersociety Energy Conversion Engineering Conference and Exhibit (IECEC) (Cat. No. OOCH37022), IEEE.

Beevor, M. (2010), Smart Building Envelopes, 4th Year Project Report, University of Cambridge, Department of Engineering.

Böke, J., Knaack, U. and Hemmerling, M. (2020), “Automated adaptive façade functions in practiceCase studies on office buildings", Automation in Construction, Vol. 113, p. 103113.

Boeke, J., Knaack, U. and Hemmerling, M. (2019), "Superposition matrix for the assessment of performance-relevant adaptive façade functions", Journal of Facade Design and Engineering, Vol. 7 No. 2, pp. 1-20.

Bostancioglu, E. (2020), "Double skin façade assessment by fuzzy AHP and comparison with AHP", Architectural Engineering and Design Management. doi: 10.1080/17452007.2020.1735292.

Brauers, W.K.M., Zavadskas, E.K., Peldschus, F. and Turskis, Z. (2008), "Multi-objective decision making for road design", Transport, Vol. 23 No. 3, pp. 183-193.

Brugnaro, G., Caini, M. and Paparella, R. (2014), "Energy saving through building envelope innovation: smart skin design", 5th International Conference on Urban Sustainability, Cultural Sustainability, Green Development, Green Structures and Clean Cars (USCUDAR '14), Recent Advances in Urban Planning, Sustainable Development and Green Energy, Florence, November 22-24, pp. 35-44.

Bui, D.K., Nguyen, T.N., Ghazlan, A., Ngo, N.T. and Ngo, T.D. (2020), "Enhancing building energy efficiency by adaptive façade: a computational optimization approach", Applied Energy, Vol. 265, p. 114797.

Cheong, K.H., Teo, Y.H., Koh, J.M., Acharya, U.R. and Yu, S.C.M. (2020), “A simulation-aided approach in improving thermal-visual comfort and power efficiency in buildings", Journal of Building Engineering, Vol. 27, p. 100936.

Chloë, M. (2016), Structural Adaptive Façades, Master's Dissertation, Ghent University, Ghent.

Chung, S., Lee, A.H.I. and Pearn, W.L. (2005), “Analytic network process (ANP) approach for product mix planning in semiconductor fabricator", International Journal of Production Economics, Vol. 96, pp. 15-36.

Crespi, M. and Persiani, S.G.L. (2019), "Rethinking adaptive building skins from a life cycle assessment perspective", Journal of Facade Design and Engineering, Vol. 7 No. 2, pp. 21-43. 
ECAM

29,1

De Marco Werner, C. (2013), "Transformable and transportable architecture: analysis of buildings components and strategies for project design", Master's Thesis, Universitat Politècnica de Catalunya, Escuela Técnica Superior de Arquitectura de Barcelona, Barcelona.

Domingues, P., Carreira, P., Vieira, R. and Kastner, W. (2016), "Building automation systems: concepts and technology review", Computer Standards and Interfaces, Vol. 45, pp. 1-12, doi: 10.1016/j.csi. 2015.11.005.

EC (European Commission) (2012), Directive 2012/27/EU of the European Parliament and of the Council of 25 October 2012 on Energy Efficiency, Amending Directives2009/125/EC and 2012/ 30/EU and Repealing Directives 2004/8/EC and 2006/32/EC.

Elzeyadi, I. (2017), "The impacts of dynamic façade shading typologies on building energy performance and occupant's multi-comfort”, Architectural Science Review, Vol. 60 No. 4, pp. 316-324.

Favoino, F., Doya, M., Loonen, R.C.G.M., Goia, F., Bedon, C. and Babich, F. (Eds) (2018), Building Performance Simulation and Characterisation of Adaptive Facades - Adaptive Facade Network, TU Delft Open, Delft.

Ferguson, S., Siddiqi, A., Lewis, K. and De Weck, O. (2007), "Flexible and reconfigurable systems: nomenclature and review", ASME 2007 International Design Engineering Technical Conferences and Computers and Information in Engineering Conference, Las Vegas, Nevada, pp. 249-263.

Fortmeyer, R. and Linn, C.D. (2014), Kinetic Architecture: Design for Active Envelope, The Images Publishing Group.

Fox, M.A. and Yeh, B.P. (1999), "Intelligent kinetic systems in architecture", 1st International Workshop on Managing Interactions in Smart Environments (MANSE '99), Dublin, pp. 91-103.

Görener, A. (2009), "Use of analytic network process in choosing cutter team supplier", Journal of Aerospace Technology and Management, Vol. 4 No. 1, pp. 99-110.

Gür, Ş., Hamurcu, M. and Eren, T. (2016), "Using analytic network process and goal programming methods for Project selection in the public institution", Les Cahiers duMECAS, Vol. 13, pp. 36-51.

Heiselberg, P., Andresen, I., Perino, M. and Van Der Aa, A. (2006), "Integrating environmentally responsive elements in buildings", Proceedings of the 27th AIVC Conference, Lyon, France, November 20-22.

Hopfe, C.J., Emmerich, M.T., Marijt, R. and Hensen, J. (2012), "Robust multi-criteria design optimization in building design", Proceedings of Building Bimulation and Optimization, Loughborough, pp. 118-125.

Hopfe, C.J., Augenbroe, G.L. and Hensen, J.L. (2013), "Multi-criteria decision making under uncertainty in building performance assessment", Building and Environment, Vol. 69, pp. 81-90.

Hosseini, S.M., Mohammadi, M., Rosemann, A., Schröder, T. and Lichtenberg, J. (2019), "A morphological approach for kinetic façade design process to improve visual and thermal comfort", Building and Environment, Vol. 153, pp. 186-204.

Iommi, M. (2018), "The mediterranean smart adaptive wall. An experimental design of a smart and adaptive facade module for the mediterranean climate", Energy and Buildings, Vol. 158, pp. $1450-1460$.

Kadoić, N. (2018), "Characteristics of the analytic network process, a multi-criteria decision-making method”, Croatian Operational Research Review, Vol. 9 No. 2, pp. 235-244.

Kermanshachi, S., Dao, B., Shane, J. and Anderson, S. (2016), "An empirical study into identifying Project complexity management strategies", Procedia Engineering, Vol. 145, pp. 603-610.

Knaack, U. and Klein, T. (2008), The Future Envelope 1: A Multidisciplinary Approach, IOS Press, Amsterdam, Vol. 8. 
Kolodziej, P. and Rak, J. (2013), "Responsive building envelope as a material system of autonomous agent", Open Systems: Proceedings of the 18th International Conference on Computer-Aided Architectural Design Research in Asia, pp. 945-954.

Lee, E., Selkowitz, S., Bazjanac, V., Inkarojrit, V. and Kohler, C. (2002), High-performance Commercial Building Facades, Building Technologies Program, Environmental Energy Technologies Division, Ernest Orlando Lawrence Berkeley National Laboratory, University of California, Berkeley, CA.

Loonen, R.C.G.M. (2010), Overview of 100 Climate Adaptive Building Shells, Eindhoven University of Technology, Eindhoven.

Loonen, R.C., Trčka, M., Cóstola, D. and Hensen, J.L. (2013), "Climate adaptive building shells: state-ofthe-art and future challenges", Renewable and Sustainable Energy Reviews, Vol. 25, pp. 483-493.

Loonen, R.C.G.M., Hoes, P. and Hensen, J.L.M. (2014), "Performance prediction of buildings with responsive building elements challenges and solutions", Proceedings of the 2014 Building Simulation and Optimization Conference (BSO14), pp. 23-24.

Loonen, R.C.G.M., Rico-Martinez, J.M. and Favoino, F. (2015), "Design for façade adaptability-towards a unified and systematic characterization", Proceedings of 10th Conference on Advanced Building Skins, Bern.

Mallasi, Z. (2019), "Designing with pixels: parametric thinking for patterning dynamic building facades", Engineering Construction and Architectural Management.

Masri, Y. (2015), "Intelligent building envelopes: design and applications", Proceedings of the International Conference on Building Envelope Design and Technology, Graz Advanced Building Skins 2015, pp. 37-46.

Meagher, M. (2015), "Designing for change: the poetic potential of responsive architecture”, Frontiers of Architectural Research, Vol. 4 No. 2, pp. 159-165.

Michael, A., Gregoriou, S. and Kalogirou, S.A. (2018), "Environmental assessment of an integrated adaptive system for the improvement of indoor visual comfort of existing buildings", Renewable Energy, Vol. 115, pp. 620-633.

Mirza, M.S., Saeed, M. and Luce, C. (2019), "Determination of the fuzzy measures for multicriteria and optimal design of a building façade using Choquet integrals", Journal of Building Engineering. doi: 10.1016/j.jobe.2019.100877.

Moghtadernejad, S., Chouinard, L.E. and Mirza, S. (2018), "Multi-criteria decision-making methods for preliminary design of sustainable facades", Journal of Building Engineering, Vol. 19 Sep, pp. 181-190, doi: 10.1016/j.jobe.2018.05.006.

Nadoushani, Z.S.M., Akbarnezhad, A., Jornet, J.F. and Xiao, J. (2017), "Multi-criteria selection of façade systems based on sustainability criteria", Building and Environment, Vol. 121, pp. 67-78.

Ochoa, C.E. and Capeluto, I.G. (2008), "Strategic decision-making for intelligent buildings: comparative impact of passive design strategies and active features in a hot climate", Building and Environment, Vol. 43 No. 11, pp. 1829-1839.

Pastore, L. and Andersen, M. (2019), "Building energy certification versus user satisfaction with the indoor environment: findings from a multi-site post-occupancy evaluation (POE) in Switzerland, Build”, Environ, Vol. 150, pp. 60-74.

Penadés-Plà, V., García-Segura, T., Martí, J.V. and Yepes, V. (2016), “A review of multi-criteria decision-making methods applied to the sustainable bridge design", Sustainability, Vol. 8 No. 12 , p. 1295.

Perino, M. and Serra, V. (2015), "Switching from static to adaptable and dynamic building envelopes: a paradigm shift for the energy efficiency in buildings", Journal of Facade Design and Engineering, Vol. 3 No. 2, pp. 143-163.

Pierleoni, A., Serra, V., Bianco, L. and Kindinis, A. (2015), "Innovative technologies for transparent building envelopes: experimental assessment of energy and thermal comfort data to facilitate 
ECAM

29,1

the decision-making process", International Conference on Innovations in Construction, May 11-12, 2015, CIGOS Paris.

Raphael, B. (2014), "Multi-criteria decision making for the design of building façade", Computing in Civil and Building Engineering, pp. 1650-1658.

Rizi, R.A. and Eltaweel, A. (2021), "A user detective adaptive facade towards improving visual and thermal comfort", Journal of Building Engineering, Vol. 33, p. 101554.

Romano, R., Aelenei, L., Aelenei, D. and Mazzuchelli, E.S. (2018), "What is an adaptive façade? Analysis of Recent Terms and definitions from an international perspective", Journal of Facade Design and Engineering, Vol. 6, pp. 65-76.

Romano, R., Gallo, P. and Donato, A. (2021), "Smart materials for adaptive façade systems. The case study of SELFIE components", in Littlewood, J., Howlett, R.J. and Jain, L.C. (Eds), Sustainability in Energy and Buildings 2020. Smart Innovation, Systems and Technologies, Springer, Singapore, Vol. 203, doi: 10.1007/978-981-15-8783-2_24.

Sánchez, M.N., Giancola, E., Blanco, E., Soutullo, S. and Suárez, M.J. (2020), "Experimental validation of a numerical model of a ventilated façade with horizontal and vertical open joints", Energies, Vol. 13 No. 1, p. 146.

Saaty, T.L. (1980), The Analytic Hierarchy Process, McGraw-Hill, New York, NY.

Saaty, T.L. (1996), Theory and Applications of the Analytic Network Process: Decision Making with Benefits, Opportunities, Costs, and Risks, RWS Publications, Pittsburgh.

Saaty, T.L. and Özdemir, M.S. (2005), The Encyclion: A Dictionary of Decisions with Dependence and Feedback Based on the Analytic Network Process, RWS Publications.

Sadineni, S.B., Madala, S. and Boehm, R.F. (2011), "Passive building energy savings: a review of building envelope components", Renewable and Sustainable Energy Reviews, Vol. 15 No. 8, pp. 3617-3631, doi: 10.1016/j.rser.2011.07.014.

Sandak, A., Sandak, J., Brzezicki, M. and Kutnar, A. (2019), Bio-based Building Skin. Environmental Footprints and Eco-Design. Of Products and Processes, Springer Open, p. 193.

Santos, R.A., Flores-Colen, I., Simões, N.V. and Silvestre, J.D. (2020), “Auto-responsive technologies for thermal renovation of opaque facades", Energy and Buildings, 109968.

Šaparauskas, J.E., Zavadskas, E.K. and Turskis, Z. (2011), "Selection of facade's alternatives of commercial and public buildings based on multiple criteria", International Journal of Strategic Property Management, Vol. 15 No. 2, pp. 189-203.

Sasirekha, V., Ilangkumaran, M. and Chandrasekar, C. (2015), "Heterogeneous wireless network vertical handoff decision using a hybrid multicriteria decision making technique", International Journal of Computational Science and Engineering, Vol. 10 No. 3, pp. 263-280.

Sayyadi, R. and Awasthi, A. (2018), "An integrated approach based on system dynamics and ANP for evaluating sustainable transportation policies", International Journal of Systems Science: Operations and Logistics, Vol. 7 No. 2, pp. 182-191.

Schumacher, M., Schaeffer, O. and Voght, M.M. (2010), Move. Architecture in Motion - Dynamic Components and Elements, Birkhauser, Basel.

Sezegen, A. and Edis, E. (2020), "Product innovation types: a discussion considering building facade products”, Engineering Construction and Architectural Management, Vol. 27 No. 9, pp. 2379-2408.

Si, J., Marjanovic-Halburd, L., Nasiri, F. and Bell, S. (2016), “Assessment of building-integrated green technologies: a review and case study on applications of multi-criteria decision making (MCDM) method”, Sustainable Cities and Society, Vol. 27, pp. 106-115.

Struck, C., Almeida, M., Silva, S., Mateus, R., Lemarchand, P., Petrovski, A., Rabenseifer, R., Wansdronk, R., Wellershoff, F. and de Wit, J. (2015), "Adaptive Façade Systems - review of performance requirements, design approaches, use cases and market needs", Advanced 
Building Skins, 3-4 November 2015, Bern, Super Decisions software, available at: http://www. superdecisions.com/.

Tabadkani, A., Shoubi, M.V., Soflaei, F. and Banihashemi, S. (2019), "Integrated parametric design of adaptive facades for user's visual comfort", Automation in Construction, Vol. 106, p. 102857, doi: 10.1016/j.autcon.2019.102857.

Tabadkani, A., Roetzel, A., Li, H.X. and Tsangrassoulis, A. (2020a), "A review of automatic control strategies based on simulations for adaptive facades", Building and Environment, Vol. 175, doi: 10.1016/j.buildenv.2020.106801.

Tabadkani, A., Tsangrassoulis, A., Roetzel, A. and Li, H.X. (2020b), "Innovative control approaches to assess energy implications of adaptive facades based on simulation using EnergyPlus", Solar Energy, Vol. 206, pp. 256-268, doi: 10.1016/j.solener.2020.05.087.

van der Aa, A., Heiselberg, P. and Perino, M. (2011), Designing with Responsive Buildings Elements, IEA - ECBCS Annex 44, Aalborg University.

Velikov, K. and Thun, G. (2013), "Responsive building envelopes: characteristics and evolving paradigms", Build Envel Renew Energies Integr Pract, pp. 75-92.

Vermillion, J. (2002), Phototropic Architecture: Intelligent Responses to Sunlight Stimuli, A new school of architecture for Ogerlthorpe University, Atlanta, Master's Thesis, Ball State University, Muncie, IN.

Wang, J., Beltrán, L.O. and Kim, J. (2012), "From static to kinetic: a review of acclimated kinetic building envelopes", Proceedings of the Solar Conference, Vol. 5, pp. 4022-2029.

Widianta, M.M.D., Rizaldi, T., Setyohadi, D.P.S. and Riskiawan, H.Y. (2018), "Comparison of multicriteria decision support methods (AHP, TOPSIS, SAW \& PROMENTHEE) for employee placement”, Journal of Physics: IOP Conference Series, Vol. 953 No. 1, p. 12116.

Wong, J.K. and Li, H. (2008), "Application of the analytic hierarchy process (AHP) in multi-criteria analysis of the selection of intelligent building systems", Building and Environment, Vol. 43 No. 1, pp. 108-125.

Yücelgazi, F. and Yitmen, I. (2020), "An ANP model for risk response assessment in large scale bridge projects”, Civil Engineering and Environmental Systems, Vol. 37 Nos 1-2, pp. 1-27, doi: 10.1080/ 10286608.2019.1702030.

Yüksel, İ. and Dağdeviren, M. (2007), "Using the analytic network process (ANP) in a SWOT analysisA case study for a textile firm”, Information Sciences, Vol. 177 No. 16, pp. 3364-3382.

Zavadskas, E.K., Liias, R. and Turskis, Z. (2008), "Multi-attribute decision-making methods for assessment of quality in bridges and road construction: state-of-the-art surveys", The Baltic Journal of Road and Bridge Engineering, Vol. 3 No. 3.

Zavadskas, E.K., Antuchevičienė, J., Šaparauskas, J. and Turskis, Z. (2013), "Multi-criteria assessment of facades' alternatives: peculiarities of ranking methodology", Procedia Engineering, Vol. 57, pp. 107-112.

\section{Corresponding author}

Ibrahim Yitmen can be contacted at: ibrahim.yitmen@ju.se

For instructions on how to order reprints of this article, please visit our website:

www.emeraldgrouppublishing.com/licensing/reprints.htm

Or contact us for further details: permissions@emeraldinsight.com 